\title{
Serum Otologus dan human Epidermal Growth Factor (hEGF) Mempercepat Proliferasi dan Migrasi Keratinosit pada Proses Re-Epitelisasi
}

\author{
Syennie Sari Agung, ${ }^{1}$ Iman Permana Maksum, ${ }^{2}$ Toto Subroto ${ }^{2}$ \\ ${ }^{1}$ Program Studi Magister Ilmu Kimia Fakultas Matematika dan Ilmu Pengetahuan Alam Universitas Padjadjaran \\ ${ }^{2}$ Program Studi Ilmu Kimia Fakultas Matematika dan Ilmu Pengetahuan Alam Universitas Padjadjaran
}

\begin{abstract}
Abstrak
Penggunaan serum otologus merupakan pendekatan terapeutik yang direkomendasikan untuk mengobati beberapa jenis penyakit yang bersifat kronis, menahun bahkan dapat bertahan seumur hidup. Serum otologus mengandung epidermal growth factor (EGF) yang dapat menstimulasi proses migrasi dan proliferasi keratinosit pada proses re-epitelisasi dalam penyembuhan luka. Penambahan hEGF pada serum otologus dilakukan sebagai upaya untuk mempercepat proses penyembuhan luka. Pengujian aktivitas dilakukan dengan mengukur proliferasi dan migrasi sel keratinosit menggunakan cell line HaCaT. Proliferasi sel diukur dengan metode Water Soluble Tetrazolium-8 (WST-8) dan migrasi sel diukur dengan metode Scratch Assay. Variasi konsentrasi hEGF yang ditambahkan adalah 0,$5 ; 1 ; 5 ; 10 ; 25$ dan $50 \mathrm{ng} / \mathrm{mL}$. Terdapat perbedaan yang bermakna pada hasil proliferasi sel HaCaT yang ditambahkan hEGF dan konsentrasi optimal pada penambahan hEGF $25 \mathrm{ng} / \mathrm{mL}(\mathrm{p}<0,05)$, sedangkan penambahan variasi konsentrasi hEGF pada serum otologus tidak menunjukkan perbedaan yang bermakna terhadap proliferasi sel HaCaT $(p>0,05)$. Penambahan hEGF pada serum otologus terlihat peranannya dalam mempercepat laju migrasi sel. Dalam waktu 18 jam, persentasi migrasi sel HaCaT yang diberikan hEGF dan serum otologus adalah 55-70\% kemudian menjadi 65-80\% dalam waktu 24 jam, sedangkan yang diberikan hEGF saja 25-45\% dan dalam waktu 24 jam meningkat menjadi 35-70\%. [MKB. 2016;48(4):205-10]
\end{abstract}

Kata kunci: hEGF, proliferasi dan migrasi, re-epitelisasi, serum otologus

\section{Autologous Serum and human Epidermal Growth Factor (hEGF) Accelerate Keratinocyte Proliferation and Migration during Re-epithelialization Process}

\begin{abstract}
Autologous serum is used as a therapeutic approach recommended to treat certain types of chronic diseases that can even last a lifetime. Autologous serum contains Epidermal Growth Factor (EGF), which can stimulate the migration and proliferation of keratinocytes in the re-epithelialization process in wound healing. The addition of hEGF on autologous serum is a part of efforts to accelerate the wound healing process. Tests were performed by measuring proliferation and migration activities of keratinocytes cells using HaCaT cell line. The cell proliferation was measured using Water Soluble Tetrazolium-8 (WST-8) method while the cell migration was measured using Scratch Assay method. Variations in the concentration of hEGF added were 0.5, 1, 5, 10, 25, and $50 \mathrm{ng} / \mathrm{mL}$. There were significant differences in the results of cell proliferation in hEGF-added HaCaTcells and the optimum concentration was seen in $25 \mathrm{ng} / \mathrm{mL}$ hEGF group $(\mathrm{p}<0.05)$. On the contrary, the addition of various concentrations of $\mathrm{hEGF}$ in autologous serum resulted in no significant difference in HaCaT cell proliferation ( $p>0$ , 05). The addition of hEGF and autologous serum showed a visible role in accelerating the pace of cell migration. Within 18 hours, the percentage of cell migration in HaCaT cells added by hEGF and autologous serum reaches $55-70 \%$ and then $65-80 \%$ within 24 hours while HaCaT cells that receive hEGF only only reaches $25-45 \%$ cell migration which increases to 35-70\% within 24 hours. [MKB. 2016;48(4):205-10]
\end{abstract}

Key words: autologous serum, hEGF, proliferation and migration, re-epithelialization

Korespondensi: Syennie Sari Agung, S.ST, Program Studi Magister Ilmu Kimia Fakultas Matematika dan Ilmu Pengetahuan Alam Universitas Padjadjaran Bandung, mobile 08122066010,e-mail syennie_74@yahoo.com 


\section{Pendahuluan}

Penggunaan serum otologus merupakan pendekatan terapeutik yang direkomendasikan untuk mengobati beberapa jenis penyakit. Pada umumnya penyakit tersebut bersifat kronis, menahun bahkan dapat bertahan seumur hidup. Perkembangan serum otolugus berawal dari penggunaan autologus cell theraphy (ACT) yang memiliki kemampuan yang besar dalam proses peremajaan. Serum otologus pertama kali digunakan pada tahun 1985 untuk pemulihan permukaan okular mata yang rusak akibat transplantasi konjungtival. ${ }^{1}$ Penggunaan serum otologus dalam bentuk tetes mata merupakan pendekatan terapeutik yang direkomendasikan untuk mengobati kerusakan permukaan okular seperti pada kerusakan epitelial mata yang menetap (persistent epithelial defect/PED) dan Keratoconjuctivitis sicca (KCS) atau yang sering disebut dengan penyakit mata kering (dry eye). ${ }^{2}$ Sejak saat itu pengobatan dengan serum otologus diaplikasikan secara luas dalam bidang kedokteran modern seperti ortopedi, dermatologi, bedah plastik, dan kosmetika. ${ }^{1-3}$

Pengobatan serum otologus memberikan hasil klinis yang lebih baik karena tidak menimbulkan reaksi alergi, memperkecil risiko terjadi reaksi immunologi secara sistemik, mencegah reaksi ketidakcocokan serta menghindari penularan penyakit. ${ }^{1,3}$

Serum otologus tersebut mengandung faktor pertumbuhan seperti epidermal growth factor (EGF) dan transforming growth factor beta (TGF- $\beta$ ), fibronektin, vitamin $\mathrm{E}$ dan vitamin A. Serum otologus juga mengandung immunoglobulin seperti IgG, IgA, lisozim dan faktor suplemen yang bersifat bakterisida. ${ }^{4}$ EGF yang terdapat dalam serum otologus dapat menstimulasi proses migrasi dan proliferasi keratinosit pada proses re-epitelisasi dalam penyembuhan luka. Re-epitelisasi merupakan komponen penting dalam proses penyembuhan luka dan dipergunakan sebagai parameter keberhasilan penyembuhan. Tanpa proses reepitelisasi, proses penyembuhan luka tidak akan terjadi. ${ }^{5,6}$ EGF disekresi oleh trombosit, makrofag dan fibroblas, serta berperan dalam paracrine fashion pada sel epitel. ${ }^{5,7}$

Epidermal growth factor juga memegang peranan penting dalam pembentukan granulasi jaringan dan secara in vitro dapat merangsang migrasi dan proliferasi keratinosit. ${ }^{7,8}$ Terapi luka dengan EGF topikal akan meningkatkan proses penyembuhan luka dan mempersingkat waktu penyembuhan. ${ }^{5,7}$
Dalam upaya meningkatkan aktivitas serum otologus maka perlu ditambahkan hEGF dalam berbagai variasi konsentrasi sehingga diperoleh konsentrasi yang optimal dalam mempercepat proses penyembuhan luka.

Pengujian aktivitas serum otologus dengan penambahan hEGF secara in vitro dilakukan dengan mengukur proses proliferasi dan migrasi sel menggunakan human epithelial cell line HaCaT (human adult calcium temperature). HaCaT merupakan cell line epitel manusia yang berasal dari kulit dewasa dan dipergunakan sebagai pemodelan dalam pengukuran migrasi dan prolifersi keratinosit selama proses re-epitilisasi. Proses proliferasi dilaksanakan menggunakan metode Water Soluble Tetrazolium-8 (WST-8) dan migrasi sel menggunakan metode Scratch Assay. ${ }^{9,10}$

\section{Metode}

Penelitian bersifat studi komparatif dan uji non klinis. Subjek penelitian menggunakan serum otologus dan human cell line HaCaT. Pengambilan darah donor dilakukan di Patologi Klinik RSHS Bandung menggunakan sistem vakutainer dan pemeriksaan EGF serum menggunakan metode sandwich ELISA. Proliferasi dengan metode WST8 , nilai absorbansi yang diperoleh menunjukkan jumlah sel yang hidup. Migrasi sel dengan metode Scratch Assay yang mempergunakan goresan sebagai pemodelan untuk luka. Lebar goresan dihitung dalam waktu tertentu dan dinyatakan dalam \%migrasi. Hasil proliferasi sel diolah dengan software Minitab 17 dan migrasi sel dengan Excel 2010. Hasil uji statistik dianggap bermakna bila nilai $\mathrm{p}<0,05$.

\section{Hasil}

Serum otologus yang diperoleh dari $30 \mathrm{~mL}$ darah adalah $12 \mathrm{~mL}$ dan hasil pengukuran dengan ELISA menunjukkan konsentrasi EGF dalam serum sebesar $490 \mathrm{ng} / \mathrm{mL}$. Pengukuran proliferasi sel dengan penambahan hEGF pada konsentrasi 0,$5 ; 1 ; 5 ; 10 ; 25$; dan $50 \mathrm{ng} / \mathrm{mL}$ ditunjukkan pada Gambar 1 . Analisis data menunjukkan nilai $\mathrm{p}<0,05$ yang berarti terdapat perbedaan yang bermakna dari setiap penambahan konsentrasi hEGF terhadap proliferasi sel. Analisis Tukey dalam Minitab 17 menunjukkan terdapat dua golongan sebaran data, yaitu kelompok A dan kelompok B.

Proliferasi sel dengan penambahan serum 


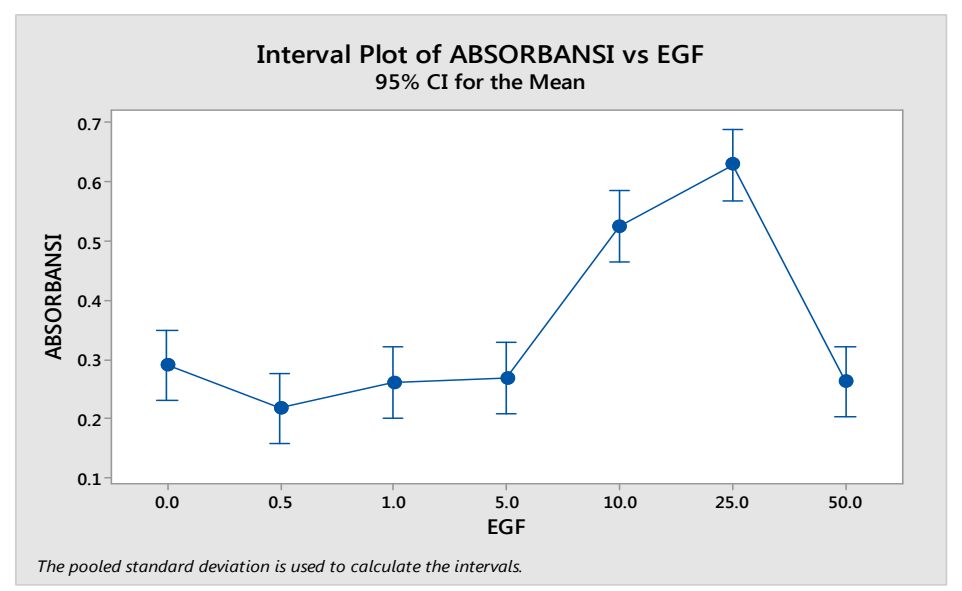

Gambar 1 Hasil Pengukuran Proliferasi pada Kultur Sel yang ditambahkan Beberapa Konsentrasi hEGF. Absorbansi sebanding dengan jumlah sel yang hidup. Analisis Tukey menunjukkan kelompok A terdiri atas penambahan hEGF pada konsentrasi $10 \& 25 \mathrm{ng} / \mathrm{mL}$ sedangkan kelompok B terdiri atas kontrol dan penambahan hEGF pada konsentrasi 0,5; 1; 5; $50 \mathrm{ng} / \mathrm{mL}$

otologus dan berbagai konsentrasi hEGF dapat dilihat pada oleh Gambar 2. Hasil analisis data menunjukkan nilai $\mathrm{p}=0,346$ atau $\mathrm{p}>0,05$ yang berarti tidak terdapat perbedaan yang bermakna penambahan konsentrasi hEGF dengan aktivitas serum otologus dalam menstimulasi proliferasi sel-sel keratinosit.

Pada penelitian ini, pengukuran migrasi sel hanya dilakukan satu kali sehingga datanya tidak bisa diolah secara statistik.Pengamatan migrasi sel dilakukan secara mikroskopik dalam waktu
18, 24, dan 48 jam. Hasil migrasi sel memberikan gambaran keberhasilan dalam penyembuhan luka. Keratinosit dari human cell line HaCaT akan bermigrasi ke arah luka yang dibuat dengan menggores kultur sel menggunakan tip kuning. Gambar 3(a) menunjukkan lebar goresan awal yang dilambangkan dengan $A_{0}$ dan Gambar 3(b) adalah lebar goresan akhir yang dilambangkan dengan $A_{1}$ persentasi migrasi dihitung dengan membandingkan lebar goresan akhir dengan goresan awal mempergunakan rumus sebagai

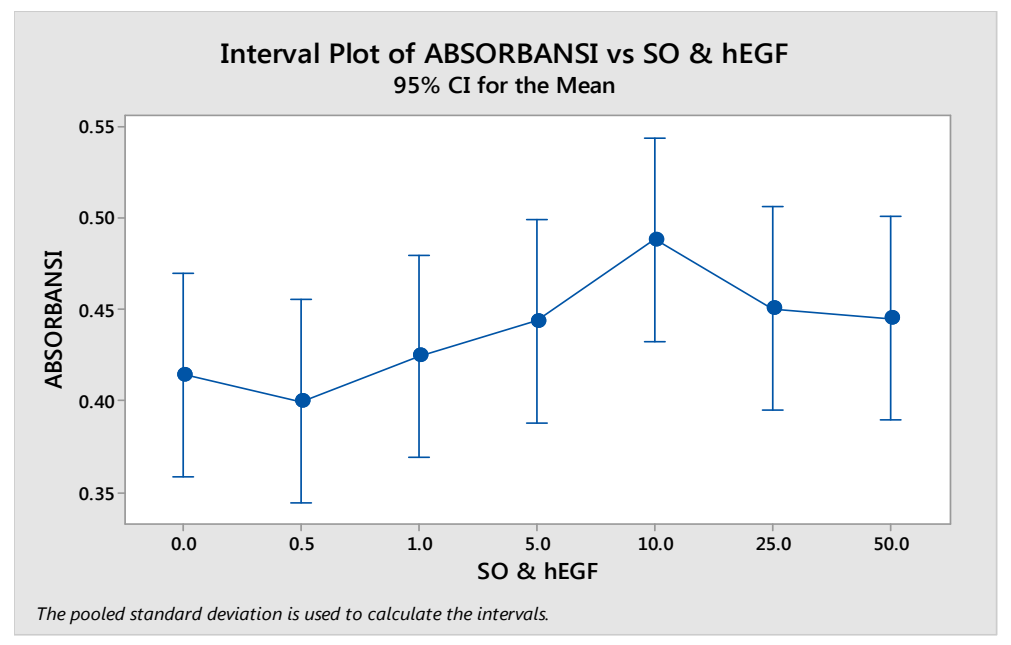

Gambar 2 Hasil Pengukuran Proliferasi Sel pada Penambahan Beberapa Konsentrasi hEGF pada Serum Otologus dan Analisis Tukey pada Minitab 17 Menunjukkan Semua Data Terdapat pada Satu Kelompok 

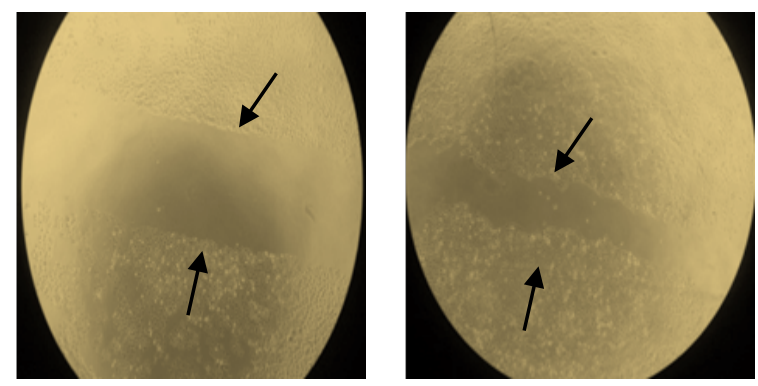

Gambar 3 (a) Lebar Goresan Awal (b) Lebar Goresan akhir

berikut: ${ }^{10}$

$$
\% \text { migrasi }=\left[\left(A_{0}-A_{1}\right) / A_{0}\right] \times 100
$$

Persentasi migrasi sel selama 18, 24, dan 42 jam kelompok yang diberikan hEGF saja dengan yang diberikan serum otologus dan hEGF ditunjukkan pada Gambar 4,5 dan 6. Persen migrasi terbaik dalam waktu 18, 24, dan 42 jam ditunjukkan oleh kultur sel yang ditambahkan serum otologus dan hEGF.

\section{Pembahasan}

Berdasarkan Gambar 1 ternyata hasil pengukuran proliferasi sel dengan WST-8 memperlihatkan perbedaan bermakna pada aktivitas proliferasi sel dengan penambahan berbagai konsentrasi hEGF. Berdasarkan analisis Tukey pada software Minitab 17 terdapat dua kelompok data. yaitu kelompok A yang terdiri atas penambahan hEGF 10 \& $25 \mathrm{ng} / \mathrm{mL}$ dan kelompok B yang terdiri dari penambahan 0,$5 ; 1 ; 5$; dan $50 \mathrm{ng} /$

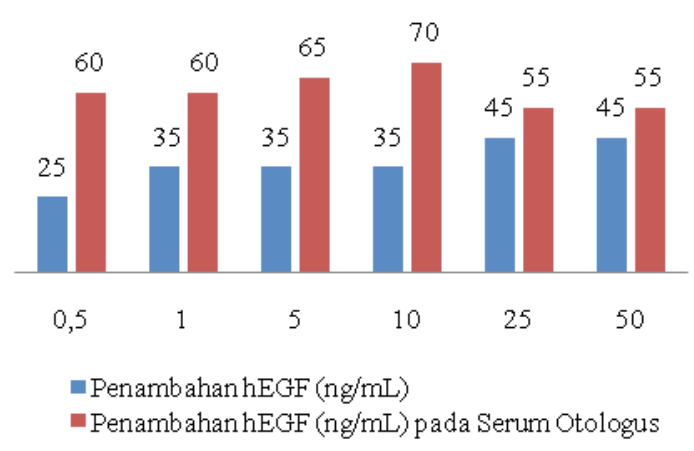

Gambar 4 Persentasi Migrasi Sel Selama 18 Jam. Persentasi migrasi sel dengan penambahan hEGF 25-45\%, sedangkan penambahan hEGF pada serum otologus $55-70 \%$

\section{Persentasi Migrasi Sel Selama 24 jam}

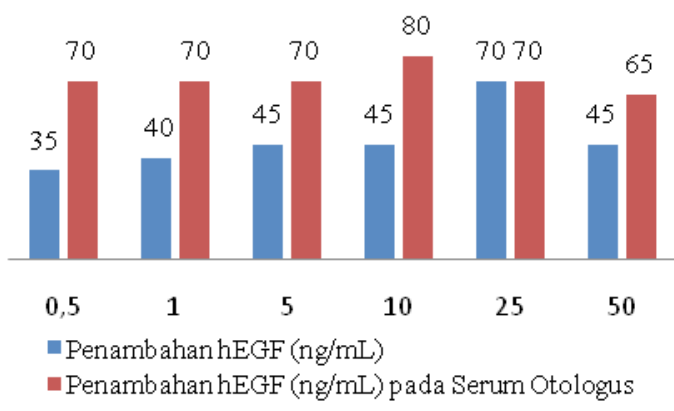

Gambar 5 Persentasi migrasi sel selama 24 jam. Persentasi migrasi sel dengan penambahan hEGF $35-70 \%$ sedangkan penambahan hEGF pada serum otologus $65-80 \%$.

mL. Apabila dibanding dengan dengan kontrol, kelompok A memberikan hasil yang signifikan terhadap peningkatan proliferasi sel keratinosit sedangkan kelompok B tidak menunjukkan peningkatan yang signifikan. Hasil proliferasi tertinggi ditunjukkan dengan penambahan hEGF $25 \mathrm{ng} / \mathrm{mL}$. hEGF pada konsentrasi tersebut dapat secara maksimal berikatan dengan reseptor EGF yang terdapat dalam membran sel, interaksi tersebut akan menyebabkan dimerisasi reseptor. Pada saat reseptor dimer, maka akan mengaktifkan tirosin kinase (TK). Fosforilasi reseptor tirosin kinase menerima sinyal protein intraseluler dan mengubah sinyal ekstraseluler menjadi transduksi sinyal intraseluler. Proliferasi seluler hasil aktivasi EGFR TK terjadi

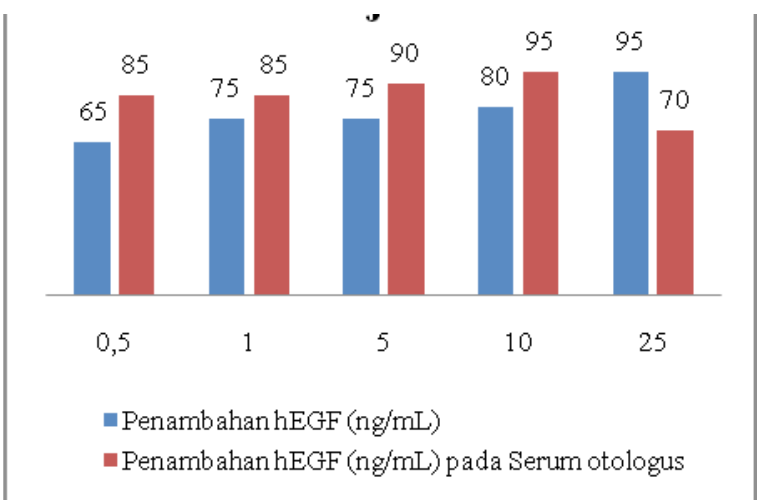

Gambar 6 Persentasi Migrasi Sel Selama 42 Jam. Persentasi migrasi sel dengan penambahan hEGF eksogen 65-95\%, sedangkan penambahan hEGF pada serum otologus 70$95 \%$ 
melalui beberapa jalur transduksi sinyal. Sinyal proliferasi jalur MAPK terjadi setelah molekul adapter mengaktivasi kompleks EGFR timbul langkah aktivasi dari Ras, Raf, MAP/Erk kinase (MEK1), dan juga extracellular regulated kinase (Erk) protein yang akan meningkatkan aktivitas faktor transkripsi untuk proliferasi dan aktivasi progresi siklus sel.

Penambahan hEGF pada kelompok B itu memperlihatkan tidak terdapatnya peningkatan proliferasi sel, bahkan dengan penambahan hEGF $50 \mathrm{ng} / \mathrm{mL}$. Jumlah sel hidup pada kultur sel dengan penambahan $50 \mathrm{ng} / \mathrm{mL}$ hEGF lebih sedikit daripada jumlah sel hidup pada kultur dengan penambahan $25 \mathrm{ng} / \mathrm{mL}$. Pengamatan secara mikroskopis dalam waktu 42 jam dengan penambahan $50 \mathrm{ng} / \mathrm{mL}$ hEGF menunjukkan densitas sel yang lebih sedikit daripada dalam waktu 24 jam.

Hasil pengamatan menunjukkan kerapatan sel yang besar terjadi pada waktu 24 jam. Kepadatan sel yang tinggi ini menyebabkan persaingan yang tinggi pula antar sel untuk mendapatkan nutrisi sehingga sel stres dan mengalami perubahan metabolik yang tidak dapat diadaptasi oleh sel. Sel yang tidak mampu beradaptasi terhadap stimulus akan mengakibatkan kerusakan DNA sehingga keseimbangan dalam sel terganggu dan berujung kematian sel.

Bila dibanding dengan serum otologus sebagai kontrol maka penambahan berbagai konsentrasi hEGF pada serum otologus tidak memberikan pengaruh dalam meningkatkan proliferasi sel keratinosit dalam proses re-epitelisasi (Gambar 2). Walaupun terdapat peningkatan absorbansi pada setiap penambahan hEGF terhadap serum otologus, tetapi tidak menunjukkan perbedaan yang berarti $(p=0,348 / p>0,05)$. Analisis Tukey pada Minitab 17 menunjukkan semua data berada dalam satu kelompok. Walau demikian, aktivitas proliferasi sel pada penambahan serum otologus lebih baik daripada kelompok B pada Gambar 1. Hal ini menunjukkan bahwa stimulasi proliferasi sel terjadi karena aktivitas serum otologus tanpa pengaruh hEGF eksogen yang ditambahkan karena serum otologus sendiri telah mengandung beberapa faktor pertumbuhan yang berperan selama proses re-epitelisasi.

Regulasi dari proliferasi keratinosit selama re-epitelisasi bergantung pada keberadaan faktor pertumbuhan dan tingkatan diferensiasi sel serta pengikatan antarsel dengan substrat. Serum otologus tersebut mengandung faktorfaktor pertumbuhan seperti HB-EGF, EGF, TGF- $\alpha$, KGF, dan IGF (insulin like growth factor)-1 yang peranannya itu sejalan dengan HB-EGF dalam menstimulasi proliferasi keratinosit. Matriks Metaloproteinase yang merupakan komponen dari matrik ekstraseluler dan integrin akan memodulasi jalur reseptor faktor pertumbuhan dan meningkatkan aktivitas faktor pertumbuhan dalam menstimulasi proliferasi keratinosit. Dengan demikian, peranan faktor pertumbuhan, matriks ekstaselular dan integrin memegang peranan penting dalam regulasi proliferasi sel selama proses re-epitelisasi. Setelah proses reepitelisasi maka keratinosit akan kembali pada jalur diferensiasi normal dan sinyal proliferasi akan berhenti. ${ }^{5}$

Peranan penambahan serum otologus terlihat jelas pada pengamatan secara mikroskopis laju migrasi sel keratinosit. Sama halnya dengan pengujian proliferasi sel, kultur sel keratinosit mendapatkan dua perlakuan. Perlakuan yang pertama adalah penambahan hEGF eksogen dengan konsentrasi 0,$5 ; 1 ; 5 ; 10 ; 25 ; 50 \mathrm{ng} / \mathrm{mL}$ dan yang kedua yaitu serum otologus yang ditambahkan hEGF dengan variasi konsentrasi yang sama. Pengamatan migrasi sel dalam 18 jam menunjukkan kisaran persen migrasi kelompok kultur dengan penambahan hEGF pada serum otologus adalah $55-70 \%$ lebih besar daripada kelompok kultur dengan penambahan hEGF eksogen 25-45\% (Gambar 4). Hal ini terlihat pula pada pengamatan migrasi sel selama 24 jam. Persen migrasi sel kelompok 1 berkisar 35$45 \%$ sedangkan kelompok 2 berkisar $65-85 \%$ (Gambar 5). Pada akhirnya kedua kelompok dapat mencapai persen migrasi sebesar 95\% dalam waktu 42 jam (Gambar 6). Pada kelompok 1 ditunjukkan oleh penambahan hEGF $25 \mathrm{ng} / \mathrm{mL}$, sedangkan pada kelompok 2 oleh penambahan hEGF $10 \mathrm{ng} / \mathrm{mL}$ pada serum otologus. Hal ini memberikan gambaran bahwa penambahan 10 $\mathrm{ng} / \mathrm{mL}$ hEGF pada serum otologus sebanding dengan penambahan hEGF $25 \mathrm{ng} / \mathrm{mL}$ secara tunggal. Bahkan, jika melihat hasil pengamatan migrasi sel selama 24 jam, penambahan $25 \mathrm{ng} /$ mL hEGF memerlukan waktu 24 jam untuk mencapai 70\% migrasi sel, sedangkan hEGF 10 $\mathrm{ng} / \mathrm{mL}$ yang ditambahkan pada serum otologus hanya memerlukan waktu 18 jam (Gambar 4 dan 5).

Hal ini disebabkan oleh karena hEGF yang ditambahkan pada serum otologus akan dapat berinteraksi dengan faktor-faktor pertumbuhan lainnya seperti HB-EGF, EGF, TGF- $\alpha$, sedangkan transaktif EGFR akan mestimulasi migrasi keratinosit serta menginduksi ekspresi keratin 6 (k6) dan k16. ${ }^{7}$ Pada saat sel monolayer diberikan goresan maka sel-sel disekitar goresan akan mati sehingga menstimulasi sel-sel yang di pinggir 
untuk bermigrasi ke arah goresan. Pertamatama sel di pinggir goresan akan kehilangan sifat adhesi antar sel sehingga sel akan bermigrasi ke area yang kosong. Bersamaan dengan migrasi sel maka terjadi pula proses proliferasi di daerah pinggir goresan sampai area goresan tertutup.

Simpulan, penambahan hEGF tersebut dapat meningkatkan proses proliferasi dan migrasi sel-sel keratinosit, sedangkan aktivitas serum otologus pada proses proliferasi sel tidak lagi dipengaruhi oleh penambahan hEGF. Peranan hEGF pada serum otologus terlihat peningkatan laju migrasi sel keratinosit. Aktivitas proliferasi sel keratinosit yang paling tinggi ditunjukkan pada penambahan $25 \mathrm{ng} / \mathrm{mL}$ hEGF eksogen, sedangkan migrasi sel terbaik ditunjukkan oleh penambahan $10 \mathrm{ng} / \mathrm{mL}$ hEGF eksogen pada serum otologus.

\section{Daftar Pustaka}

1. Kazmi B, Inglefield CJ, Lewis MP. Autologous cell therapy: current treatments and future prospects. Wound Res. 2009;21(9):234-42.

2. Quinto GG, Campos M, Behrens A. Autologous serum for ocular surface diseases. Arq Bras Oftalmol. 2008;71(6 Suppl):47-54.

3. Kumar S, Mahajan BB, Kaur S, Singh A. Autologus therapies in dermatology. J Clin Aesthet Dermatol. 2014;7(12):38-45.

4. López-García JS, García-Lozano I, Rivas L,
Martínez-Garchitorena J. Use of autologus serum in ophthalmic practice. Arch Soc Esp Oftalmol. 2007;82(1):9-20.

5. Pastar I, Stojadinovic O, Yin NC, Ramirez H, Nusbaum AG, Sawaya A, dkk. Epitelization in wound healing: a comprehensive review. Adv Wound Care (New Rochelle). 2014;3(7): 445-64.

6. Cordeiro JV, Jacinto A. The role of transcription-independent damage signals in the initiation of epithelial wound healing. Nature Rev Mol Cell Biol. 2013;14(4):24962.

7. Yu FX, Yin J, Xu K, Huang J. Growth factor and corneal epithelial wound healing. Brain Res Bull. 2010;81(2-3):229-35.

8. Rao K, Farley W, Pflugfelder S. Association between hifh tear epidermal growth factor levels and corneal subepithelial fibrosis in dry eye condition. Invest Opthalmol Vis Sci. 2010;51(2):844-9.

9. Ngamwongsatit P, Banada PP, Panbangred W, Bhunia AK. WST-1-based cell sytotoxicity assay as a substitute for MTT-based assay for rapid detection of toxigenic Bacillus species using $\mathrm{CHO}$ cell line. J Microbiol Methods. 2008;73(3): 211-5.

10. Krishnaswamy VR, Karropati PS. Role of dermatopontin in re-epithelialization: implications on keratinocyte migration and proliferation. Sci Reports. 2014;4(7385):16. 